\title{
Media Diversity and the Politics of Criteria
}

\author{
Diversity Assessment and Technocratisation \\ of European Media Policy
}

\author{
KARI KARPPINEN
}

\begin{abstract}
Diversity and pluralism are foundational principles that seem to underlie much of the arguments in European communication and media policy. Consequently, the positive value associated with these concepts can be exploited in arguments for various and often-incompatible objectives. This paper discusses the uses and implications of different definitions and empirical objectifications of media diversity in media policy with a particular focus on how certain definitions and political rationalities become institutionalized and normalized in expert and policy discourses. It is argued in the article that the growing body of research on media diversity as a measurable concept implies a shift from the normative and political questions to more narrowly defined technocratic and market-driven definitions of media and culture, a move which itself is not without normative and political implications.
\end{abstract}

Key Words: media diversity, public policy, governance, media performance assessment, technocratisation

\section{Introduction}

Media diversity constitutes one of the key objectives in the name of which arguments are made in both theoretical and political debates on media policy. As such, diversity and pluralism are foundational values that hardly anyone is opposed to. Opinions on the meaning and nature of these concepts are many though and they embody some of central conflicts in contemporary media policy. Respectively, the aspects and levels on which media diversity can be conceptualized have been subject to numerous analyses ${ }^{1}$. The purpose of this paper, however, is neither to review them nor to offer new definitions. Instead, the article will follow Nikolas Rose's (1999: 29-30) claim that instead of analysing what concepts or words mean, it is sometimes more important to analyse what they do; what they make possible, the sentiments they mobilize, and the 'regimes of truth' they constitute. Consequently, my intention is not to seek the foundations of the concept of media diversity or to dwell on its possible definitions, but to locate some contradictions and lines of power in its current use. 
Based on the undisputed merits of social, political and cultural pluralism, diversity and variety in the media are desirable ends in themselves. But as McLennan (1995: 7) has noted, the constitutive vagueness of pluralism as a social value gives it enough ideological flexibility so that it is capable of signifying reactionary things in one phase of the debate and progressive things in the next. Similarly, in media policy the positive value of pluralism and diversity has been exploited in arguments for various and often incompatible objectives: for free competition as well as further public interventions and public service obligations. This ambiguity raises a question of whether media diversity in substance amounts to anything more than a fetished catch-phrase.

The article aims to examine the contestation of media diversity as a political objective with a particular focus on how certain definitions and political rationalities become institutionalized and normalized in expert and policy discourses. The analysis is premised on the idea that the contestation of any ethico-political concepts can be analysed on many levels: (1) in normative and theoretical debates, (2) their political, strategic or rhetoric uses, or (3) on the level of implicit political rationalities and evaluation criteria that political considerations rely on. Each level implies a different mode of discourse, explicitly normative, political-strategic, or empirical-objective. While the explicit theoretical and political struggles are better covered in the existing literature on media diversity, I will focus particularly on the third level of contestation, what I call 'the politics of criteria'. Drawing from the recent research into the role of ideas and concepts in public policy, it can be argued that the 'success' of political ideas and paradigms often rely, not on grand ideological clashes, but on their capability to become institutionalized and embedded in the norms, standard practices and calculations of policy-making (see Hay, 2004). This also implies an aim to illustrate how contested political ideas move from one domain to another, from theory to politics and further on to the informational practices of governance, and how they are transformed in the process. The first part of the paper will thus outline the rise of the diversity discourse in European media policy and attempt to expose some of its inherent contradictions and their political implications. Employing the notion of 'governmental technologies', the final part of the paper will then discuss some of the techniques used to stabilize, or de-contest, media diversity into a supposedly objective and reliable policy indicator, internalized by policy-makers and experts alike.

Contestation of normative concepts as such is not foreign, or undesirable, to any sector of politics. The aspect of the diversity discourse that I want to focus on here is its technocratisation, i.e. attempts to bring closure to the political contestation in the name of empirical objectivity or expert knowledge. With increasing inclination to develop empirical indicators to measure media diversity, the scholarly and policy discourse on media diversity has arguably shifted to more instrumental considerations and practices that link with the general trends of technocratisation and instrumental rationality in public policy. Even in itself, media diversity as a concept alludes to objectivity and neutrality that seem to transcend the dilemmas inherent in terms such as quality or social responsibility in assessing media performance. This makes it more compatible with both the needs of technocratic expert assessment and the broader ideology of anti-paternalism, pluralism and multiculturalism in media and cultural policy.

Unfortunately, this inclusiveness also serves to veil political conflicts and antagonisms in media policy and often obscures the properly political or normative aspects of evaluating media performance and setting policy objectives. Thus, my paper is not an attempt to define but rather re-politicize and re-contest the concept of media diversity. 
After outlining the initial approach, the rationales, contradictions and political consequences of its different uses are discussed here especially in the context of regulatory objectives and evaluation criteria set for (public) broadcasting.

\section{Governing Media Performance}

To locate the current contribution theoretically, I will briefly situate the approach in terms of the tradition it draws from. Departing from most media policy analyses, politics and policy are here understood neither solely on the basis of competition between interests nor as a battle between some coherent ideological doctrines. Instead, I will focus on the definitional power that both influences the construction of policy problems and delimits the possible alternatives of dealing with them. This brings about questions on how the uses of concepts legitimate and justify certain political aims and practices, and how they form political framings of problems that guide the considerations and possible alternatives of decision-makers.

Derived from Foucault, the concept of governmentality has recently become central to analysing and understanding the rationales and techniques of political power and public policy (see Foucault, 1991; Rose \& Miller, 1992; Dean 1999; Rose, 1999). Central to this perspective is the recognition that the activities of government and regulation are always bound up with the developments in knowledge and the powers of expertise. In short, it is premised on the idea that ideas and action are mutually constitutive. As Hay (2002: 258) argues, "it is the ideas actors hold about the context in which they find themselves, rather than the context itself, which ultimately informs the way in which they behave". This implies that definitions and interpretations of concepts such as media diversity can have political effects independently of actual empirical changes in media structures.

In particular, the discussion in the article is informed by the concepts of political rationalities and governmental technologies. According to Nikolas Rose and Peter Miller (1992), any forms of governance can be analyzed in terms of their political rationalities, "the changing discursive fields within which the exercise of power is conceptualized, the moral justifications for particular ways of exercising power by diverse authorities, notions of appropriate forms, objects and limits of politics and conceptions of the proper distribution of such tasks". Governmental technologies, on the other hand, refer to the "complex of mundane programmes, calculation, techniques, apparatuses, documents and procedures through which authorities seek to embody and give effect to governmental ambitions" (ibid: 175).

Conceptual definitions and empirical objectifications of media diversity are thus analysed here as intertwining tools of political control. The recognition of governing as a complex activity, which cannot be viewed simply as the implementation of any particular political or normative theory, makes political rationalities conceptually distinct from political philosophies or ideological doctrines. It also means that political rationalities cannot be divorced from the mechanisms or technologies through which thinking about government is put into effect. The incorporation of philosophies or theories into governmental practice always necessitates connection with various administrative techniques and forms of calculation which modify, if not transform, the original theories and their objectives. Such techniques, it is argued, contribute to the governing of a certain area of social life as 'intellectual machinery' that renders the world thinkable and amenable to regulation (Rose \& Miller, 1992; Rose, 1999). In other words, 
governing a sphere requires that it can first be depicted in a way that represents it in a form in which it can enter the sphere of conscious political calculation. Events need to be transformed into political language, and furthermore into information, reports and statistics. And although necessary, these can never be neutral in a sense that they are always bound to specific political rationalities.

The fact that normatively charged concepts can easily be remoulded for any political purposes, need not necessarily be seen as negative but as an inherent aspect of political contestation. According to Rose and Miller (1992: 178), political discourse by definition is "a domain for the formulation and justification of idealized schemata for representing reality, analyzing it and rectifying it". From this perspective, analysing policy is not a question of what concepts or words, such as freedom, diversity or democracy, mean but rather of analysing what they do, the way they function in connection with other elements, what they make possible, the sentiments they mobilize, and regimes of truth they constitute (Rose 1999: 29-30). Diversity discourse thus serves here as an example of the role of expert knowledge in the production of political rationalities. Consequently, my intention is not to seek the foundations of the concept of media diversity or to offer new definitions, but to find contradictions, ambiguities and lines of power in its current use in politics. Equally, the contribution can be conceived as an attempt at scholarly self-reflection since academic research clearly is one of the main institutions of intellectual machinery that produce conceptual and empirical means applied in governing the media.

\section{The Rise of the Diversity Discourse}

The breakthrough of the 'pluralistic consensus' in Nordic and international debates on media and cultural policy is usually placed in the 70 s and 80 s. With the idea that all forms of culture contain their own criteria of quality and that no definition of quality can legitimately repudiate another, the universal basis for defining cultural quality was then broken (Nielsen 2003: 238). This applies particularly well to the media where the paternalism and elitism often associated with traditional public service values became under increasing criticism, consequently spurring the need for new legitimating principles. In television policy, the use of the term media diversity is thus linked to the debates about deregulation of electronic media that began around Europe in the 1980s, and it was in policy-making responses to the expansion of commercial broadcasting that the concept of media diversity began to gain more and more prominence in policy debates (Collins, 1998: 62; Gibbons, 2000).

According to a number of writers, defining characteristics of contemporary (postmodern) political condition in general is radical socio-political pluralism and acceptance of multiplicity and pluralism in all social experiences, identities, aesthetic and moral standards (McLennan, 1995; Mouffe, 2000; Kymlicka \& Norman, 2000). In this vein of anti-essentialism, John Keane (1992), for example, has argued that social values such as democracy and individual freedom should be conceived as means, and necessary precondition, of protecting philosophical and political pluralism, rather than as essentialist or inherent principles. On the face of it, diversity and pluralism as media policy goals would thus seem well suited to the contemporary emphasis on de-centralization and multiculturalism in social theory. Yet, this emphasis, Nielsen (2003: 238) argues, did not immediately offer new opportunities for the orientation of public policy, but instead, 
created an open situation, where the articulations and hegemonic definitions of diversity were and still are contested.

With this in mind, the development of the diversity discourse in European media policy provides an interesting example of institutionalization and normalization of a certain policy paradigm and the struggles involved in it. One powerful articulation has been the equation of diversity with freedom of choice, and the general framework of the free marketplace of ideas. Within the various discourses that emphasize socio-political pluralism, the belief in social centralism, rational progress, a homogenous public, and social engineering have all come to seem politically questionable (McLennan, 1995: 7879). Thus, pluralism, variety and choice are generally seen as the opposite of paternalism, constructing an image of media history as a continuum from public regulation and planning towards ever increasing freedom of choice for the consumer and freedom of operation for the industry. As influential as it has been, the neoliberal articulation of diversity and the market is not unquestioned though. The defenders of public service broadcasting, in particular, have adopted diversity and pluralism as the core of their remit and consequently promoted a more interventionist articulation of diversity (Collins, 1998: 62). The Council of Europe and the European Parliament, for example, have paid ample attention to public service broadcasting as a crucial institution for guaranteeing media diversity, to an extent that this commitment is now found in number of European treaties and declarations. Similarly, national legislations all around refer to diversity and pluralism as both general principles of media policy and specific justifications or demands for public service broadcasting. In other words, the free market and public service discourses rely on different political rationalities in interpreting diversity and pluralism as media policy goals, the former based on competition and freedom of choice and the latter on broader defence of 'principled pluralism', an attempt to serve the whole society with various political views and cultural values (see Van Loon 2000; Hellman, 2001; Harrison \& Woods, 2001).

However, it seems that the discourse of consumer choice has become prevalent enough to force the defenders of public service to increasingly adapt to it too. Economic modes of argumentation and economic vocabularies have come to dominate the European media politics in general and freedom of choice for consumers, in particular, has become a main value to which arguments are based on when deciding on channel licenses, norms of regulation or performance assessment (Pauwels, 1998; Venturelli, 1998; Hellman, 1999; Van Cuilenburg \& McQuail, 2003). Gibbons (2000: 307) has even suggested to this end that media diversity itself serves as a transitional concept that conveniently assists a shift from the public service dominance to the market approach. This is because it frames the discussion on the democratic role of the media as a reasonable difference of opinion between two different ways of achieving the same goal (diversity of supply). Implicit in such discourse, he argues, is the idea that through development of the new media and increased competition, the problems of market failure might be corrected and the special need for public regulation would be on the way out.

The definitional and discursive power that frames the boundaries of political discussion also depicts in the vicissitudes of media policy in the EU. While the European Parliament has consistently since the early 90 s attempted to raise the issue of media pluralism to the Commission's agenda, the attempts to build on a political and cultural definitions or pluralism and diversity have repeatedly failed due to the opposition of industry groups and the Commission, and their ability to redefine the terms of the de- 
bate (Kaitatzi-Whitlock, 1996; Sarikakis, 2004). First, the questions on pluralism and independence of the media have been relegated under the competition policy, marginalising any problems specific to the media sector (Doyle, 1997). Second, when dealing explicitly with media contents, diversity has been defined as choice between programme types or genres, raising an immediate concern with limiting the remit of public service to producing content that is not profitable or not taken care of by the commercial market (Feintuck, 1999: 59-61; Harrison \& Woods, 2001).

\section{Performance Assessment and Technocratisation of Media Policy}

In addition to the revival of pluralism in social thought, there is another and perhaps related development that is even more pertinent to the present discussion. Hay (2004), for example, has associated the institutionalization of the new neo-liberal policy-paradigm with a shift from normative to more normalized and necessitarian political rationalities. Similarly, Van Cuilenburg and McQuail (2003) have suggested that explicit references to moral and normative components in European media policy debates have largely been supplanted by more market-oriented and supposedly more pragmatic concerns. The socio-political media policy paradigm, which was shaped by normative concerns relating to the needs democracy and the social responsibility of the media, has been replaced by a new paradigm that emphasizes mostly technical and economic considerations. Such considerations are usually presented as pragmatically problem-oriented, and unlike the political practice illegitimately justified by ideologies, rational politics is characterized by treatment of social facts as more like the natural facts, requiring ever-increasing expert knowledge and objective analysis. Following from this, Hay (2004) argues, political rhetoric is increasingly couched in terms of the non-negotiable character of external, either economic or empirical-objective, imperatives, with which the various normative views on the public interest are at pains to reconcile with.

The distinction between market approach of diversity, which emphasises choice and deregulation, and the public regulation approach, which relies on cultural-political norms of cultural diversity, civic equality and universalism, is not without consequences in terms of this development. While the market definition of diversity is rather easily quantified and measured, the more qualitative and multifaceted public service ideals clearly are not. On the contrary, the remit of public service broadcasting is especially intangible and normative, embedded in the ideas of public sphere, citizenship, pluralism, creativity, national culture, all values that are notoriously difficult to define in an unambiguous way, let alone measure empirically (see Jakubowicz, 2003; Coppens, 2004).

Regardless, there is a general European trend of developing more and more specific objectives and performance criteria for (public) broadcasters to justify their accountability and efficacy. Partly the new accountability is due to the increased criticism and scrutiny of PSB in the EU and by the private broadcasting lobby. Especially the concerns related to competition policy and common market have raised the need to develop tangible criteria to distinguish the domain of public regulation as an exemption from the market principles (Harrison \& Woods, 2001: 499; Syvertsen, 2003: 167-168: Coppens, 2004). Moreover, the technocratic trends in media and cultural policy have been associated with a more general set of ideas about the reorganisation of the public sector, known as "the new public management" (Nielsen, 2003; McGuigan, 2004). According to Nielsen, the roots of these ideas are in the diminishing possibilities of political de- 
cisions to shape policy, and on the other hand, the increasing needs to control social complexity. This has created a need for new administrative instruments of control, "disciplining mechanisms that formally, but potentially also in practice, ensure central government's continued control over the tasks it has delegated to decentralised levels" (Nielsen 2003: 240).

Thus, the attraction of neutrality and objectivity evidently contribute to the popularity of diversity as the key principle of media policy. For diversity seems more neutral and less value-dependent than quality or social responsibility, making it resistant to any remnants of paternalism in media and cultural policy. Consequently, media diversity is more and more treated in the administrative discourse as an empirical construct, an indicator amenable to objective measurement. Indicators used in such administrative media performance assessment around Europe vary from very elaborate frameworks of qualitative and quantitative assessment to rough calculations of programme type diversity (see Hellman, 2001; Coppens, 2004). In any case, they indicate a commitment to diversity as a measurable concept, a tangible and empirically assessable construct rather than a justification for policy initiatives or another abstract dimension of media freedom. Thus, it seems that the idea of performance assessment based on 'reliable and objective evidence' is now firmly embedded in European media policy too, as it has been in the US for some time now (see Howley, 2005). Although there, the demand for objective and reliable empirical evidence in assessing diversity as a policy goal has also met with resistance from various public interest groups who claim that reduction of diversity to a single quantitative measure fails to account for the complexities of media landscape and substitutes mechanical devices for serious analysis of media power (ibid: 103-104).

Indeed, it is not difficult to point out several problems in the administrative discourse of diversity evaluation. To critical theorists concerned with depolitization, the emphasis on instrumental reason and expert knowledge has always been problematic. As Habermas (1996: 45) has put it, rationality in the choice of means often accompanies irrationality in orientation to values, goals and needs, essentially depriving democratic decision-making of its object. With this in mind, all attempts at definitions or measurements of media diversity involve political and normative choices and contestation over the meaningful norms and criteria of setting policy goals that cannot be reduced to mere facts and figures. Thus, attempts to impose common criteria or conceptual framework for analysing media can be seen as attempts to reach political closure, or attempts to stabilize the political contestation and establish certain criteria and concepts as hegemonic.

Following Nielsen's critique of evaluation practices in cultural policy (2003), I would concur that a formal and technocratic control discourse, with no reference to the general normative debate on the functions of the public sphere and the media, can have comprehensive consequences for the media policy as well. These would potentially include weak public debate on the normative issues related to the organisation and tasks of the media as well as arbitrariness and unintentional consequences in setting policy objectives. Instead, there is a need for reflection of evaluation criteria such as diversity in relation to overall socio-political goals for the public regulation of the media. Above all, there is a need to discuss the underlying overall rationales of media policies, such as supporting pluralistic public sphere, and their relation to other objectives such as economic growth or political integration. For employment of 'objectives criteria' in policy decision-making easily misses the fact that these are often contradictory goals whose relative priorities should be politically settled. 


\section{Diversity and the Structure of Differences}

So is more diversity always better? Belief that diversity can be absolute or linear value is easy enough to repudiate. It might seem that all things plural, diverse and open-ended are to be automatically regarded as good. But as McLennan (1995) has pointed out, in deconstructing it, we are faced with questions of the following order: Is there not a point at which healthy diversity turns into unhealthy dissonance? Does pluralism mean that anything goes? And what exactly are the criteria for stopping the potentially endless multiplication of valid ideas? Even the best known proponent of 'radical pluralism' in political philosophy, Chantal Mouffe (2000), explicitly denies the type of extreme pluralism that valorises all forms of difference and espouses heterogeneity without any limits, because for her, such pluralism crucially misses the dimension of the political. Because of its refusal to acknowledge the relations of power involved in the all "constructions of differences', such naïve pluralism is actually compatible with the liberal evasion of politics, converging with the typical liberal illusion of a pluralism without antagonism (ibid: 20).

Similarly, while media diversity clearly denotes heterogeneity on some level, it can be defined in any number of ways and it can refer to any aspect of the media: sources, outlets, opinions as well as genres and representations. In debates on media policy, diversity can refer to the extent which media contents reflect and serve various interests and opinions of the public, or it can refer to the general diffusion of media power in society on the level of ownership, economic structures, and political influence. Considering the variety in possible definitions of diversity, empirical evidence on the relations of different aspects of diversity tends to be very ambiguous too ${ }^{2}$. For instance, it is entirely possible that market competition would enhance the number and variety of program types and genres available to the public, while at the same time reducing the diversity of political views or cultural representation or even excluding some contentious issues altogether.

Consequently, there is no absolute means to define or measure media diversity, but rather it is only intelligible in relation to some criteria and definitions that are deemed more important than the others. As Van Cuilenburg (1998) puts it, media diversity always has to be 'gauged' in some way to the variations in social reality. The question arises then, how to conceptualize this relationship. How are the differences against which diversity is examined constructed, institutionalized and operationalized?

Here, most studies follow McQuail's (1992: 144-145) conceptualization, in which the media is seen to contribute to diversity in three ways: (1) by reflecting existing differences in society, (2) by giving equal access to any different points of view, or (3) by offering a wide range of choice for individuals. Each of these implies a different interpretation on the meaning of media diversity and the standard by which it should be assessed. Notably, most empirical approaches are based solely on the third, freedom of choice, while the political value of diversity would seem to rely equally on the broader conceptions of pluralism and reflection of social differences.

Further challenges to the notion of media diversity are posed by technological developments and the complexity of the contemporary media landscape. The suggested shift from the mass broadcasting model to a more differentiated and individualized narrowcast model of communication only adds to the blurring of the line between public and private communication. Although the technological development would seemingly diversify the uses of media, it has also brought about fears of fragmentation, extreme individualism, loss of common public platforms, and their consequences for the public 
sphere (see Gibbons, 2000; Sunstein, 2003). Van Cuilenburg (1998: 41) has presented some of these problems in 'diversity paradoxes', contradictions between the aspects of diversity that cannot be reconciled. For instance, more reflective diversity usually goes with less diversity in terms of equal access for all groups. Similarly, the explosion of information increases choice but also bring along waste and overload of information. Even though the expansion of channels might lead to increased choice, there is no corresponding effect on the citizens' access to relevant information. On the contrary, increase in the diversity of supply may reduce the actual consumption of diversity (exposure diversity) (Gibbons, 2000: 308-311; Van der Wurff, 2004: 216). Consequently, Van Cuilenburg (1998: 45) goes as far as claiming that these paradoxes make diversity in information and opinion completely fictious, a mythical concept with no practical meaning. For, he argues, the real issue for media policy is not lack of information but information accessibility, particularly access to new and innovative ideas and opinions of small cultural minority groups.

\section{Diversity Assessment as Governmental Technology}

In the above, I have dealt with some of the problems and normative contradictions involved with media diversity as a theoretical concept. But, as emphasized, governing a sphere cannot be viewed simply as the implementation of any particular political or normative doctrines. The incorporation of these models into governmental practice always necessitates connection with various administrative techniques and forms of calculation which modify, if not transform, the theories and their objectives. As noted earlier, political rationalities cannot be divorced from the mechanisms or technologies through which thinking is put into effect and through which they become institutionalized and normalized in the practices and calculations of policy-making.

If the debate on diversity as an objective is seen in terms of battling political rationalities, we should also take a look at the means through which they are translated into governmental technologies. Leaning on the discussion of the ambiguity of media diversity as a normative principle, I will turn to the consequences of what I see as one such technology, the conceptualization of diversity of television programming as a measurable and empirically tangible variable. There are countless approaches for assessing media performance, based on content analysis, market analysis, political economy approach and many others. In terms of diversity, information on the structural diversity of the media system has been rather easily available in the forms of research on market shares, concentration of ownership and shear number of outlets, but when diversity is regarded as referring specifically to media contents, the empirical approach becomes much more problematic both methodologically and politically.

Regardless, there is an established field of academic empirical diversity research in addition to the governmental and regulatory commissioned studies on the diversity of television programming (see Napoli, 1999; Hellman, 2001; van der Wurff, 2004; Aslama et al, 2004). In principle such research can take any aspect of diversity as a meaningful variable, but in most cases, studies on television programming have focused on the diversity of programme types. According to van der Wurff, programme-type diversity is considered is a meaningful indicator of diversity, because (1) it is deemed a relevant criteria when making viewing choices, and (2) it is deemed important policy indicator and monitor by the regulators and governments, for instance of whether (public) service broadcasters offer enough specific programme types. In truth, pragmatic reasons 
having to with the ease of operationalisation and classification probably have as much to do with it though. In any case, the interpretation of diversity in terms of programme types or genres has consequently become the common focus of both scholarly and policy debates on media diversity (van der Wurff 2004: 216).

The specifics of operationalisation can be endlessly discussed, but the focus of my criticism here is more general. Articulating diversity with any empirical index, instead of viewing it in the context of the political contestation, has political consequences more insidious than the debate on methods of measurement implies. However, by way of illustrating the choices inherent in any empirical tools, I will focus my critique on a few specific problems with this type of research and especially with the notion of programme type diversity.

First, I argue that the emphasis on freedom of choice as a normative framework is limited in terms of conceptualizing media diversity, for it presumes consumers whose differentiated preferences are best satisfied by offering a variety of different types of programming. Thus, media is conceptualized as a consumer good like any other with no reference to reflection of different social values, openness to new ideas, or other aspects associated with political and cultural pluralism. Second, the status of programme types as meaningful variable is not only incomplete but itself politically problematic. Reduction of diversity to variation of programme types reflects on the broader issues with political consequences. In particular, it marginalizes any qualitative or holistic ideals that characterize public service broadcasting. In addition, I have already argued that there are principled reasons to criticize the enchantment to empirical diversity research. By representing media diversity as a measurable variable, instead of a contested political value, it turns media policy away from values and public deliberation towards instrumental rationality and technocratic decision-making. In doing so, philosophical and political ideals that media policy declarations are reaching for are in danger of turning into mere rhetoric.

\section{The Fallacy of Free Choice}

As noted, political rationalities can be conceived as paradigms or cognitive schemas through which political problems are conceptualized. Among the central metaphors through which almost any public policy is conceived today are naturally the marketplace and 'choice'. As Zygmunt Bauman (1997) puts it, freedom of choice has become the main stratifying variable in our multidimensionally stratified societies, to an extent that choosing is everybody's fate. Only the ranges of realistic choices differ and so do the resources needed to make them.

In the tradition of critical political economy of the media, models based on free competition and choice have long been criticized for ignoring that choice is always prestructured by the conditions of competition. The belief that consumer choice directs the media in accordance with the general will of the people misses that the influence of the consumer is passive, reactive rather than proactive, and the extent of alternatives for choice is always limited by the structural effects, such as the concentration of ownership, high costs for market entry, advertising, unequal representations and political influences (Curran 2002: 227-230). More eloquently, Bauman (1999: 73-78) explains that throughout modernity, the principal tool of 'setting the agenda for choice' or preselection has been legislation, a tool which political institutions are now abandoning. However, this 'liberalisation' does not necessarily mean that the freedom of choice 
is expanding, but that the power of preselection is being ceded to other than political institutions, above all the markets themselves. Consequently, the code or criteria of preselection is changing, and among the values towards which choosers are trained orient their choices, short-term pleasure, hedonism, entertainment and other market-generated needs come to occupy a superior place. Thus, Bauman argues that the late-modern emphasis on the freedom of choice and individual autonomy has not really increased individual freedom, but has instead lead to unfreedom, transformation of a political citizen to a consumer of market goods.

The simplistic equation of media diversity to market competition and free choice thus fails to take into account the wider relations of power in which the media are situated. Contrary to the language of 'the free marketplace of ideas' where the market is seen as self-regulating and spontaneous mediator, the market itself is a politically designed institution, not a homogenous, unstructured and unregulated natural entity. As Keane (1992: 119) notes, the actual shape of the markets must always be crafted by political and legal regulation and it hardly emerges spontaneously as a neutral mediator of civil society. Secondly, any market also imposes its own criteria of preselection that necessarily limits the range of public choices.

Leaving philosophical critique aside, the prevailing definitions of diversity can also be seen as reversely analogous to the logic of marketing and its construction of hypothetic target audiences. Ien Ang (1991) criticized the biases inherent in official knowledge about television audience some time ago by drawing from Foucault's power/knowledge thematic. According to Ang, the institutional forms of knowledge production, such as ratings and target groups, construct audiences into objects of control and consequently suppress the actual complexity of understanding audiences. In a way, current diversity measurement bears a reverse analogy to this, for it reduces the cultural institution of television programming to distribution system of goods that satisfies a predefined set of hypothetical preferences. Thus, calculating indexes on the distribution of programme types sheds no light on the diversity of views and representations in the media, nor does it account for the general diffusion of media power on the structural level. However, in addition to being insufficient, such indicators can have more insidious consequences politically.

Another dubious feature of diversity indicators is their customary reliance on industry-generated data. As the original criteria for the selection of such data and criteria are often inaccessible to the public, their measure of 'objectivity' and 'reliability' must inevitably fall under suspicion. This is also a more general flaw of such administrative research. Analysing evaluation practices in cultural policy, Nielsen has concluded in general that the criteria for evaluation in such evaluation often remain poorly illuminated and the assessment appears as a goal in itself, as control for control's sake, as "secular rituals that modern, fundamentally incalculable and intractable society invents in order to maintain confidence in its own rationality" (Nielsen, 2003: 240). Taken that diversity always needs to be gauged to some external social reality, in relation to what is it gauged when it is based on already existing categories of programming, the definitions of the very same institutions whose performance it claims to assess? Is it too far-fetched to conclude that this makes up a circular argument that serves the self-legitimating function of affirming the 'rationality' of political choices and the existing media system?

I have already hinted at some particular problems with the empirical research of programme-type diversity and the institution of public service broadcasting. Quite apart from the methodological problems involved in analysing the public broadcasters per- 
formance (see Jakubowicz, 2003), there are fundamental and principled problems particularly with the notion of programme type diversity. Although public broadcasters have generally, and due to their own benefit, not been in a hurry to discredit the existing frameworks of performance assessment, there are some principled problems that are ill compatible with the ethos of public service. Defining public service broadcasting in terms of programme type or genres, an assumption which is implicit in much of the debate, is in many ways inconsistent with the broad-ranging cultural and social aspirations of PSB that are not based on any quantitative or measurable criteria (Harrison \& Woods, 2001: 495). Also implicit in much of the diversity research is an idea of a 'division of labour' between channels, but the division of labour applies only to supply, and not to exposure (Napoli, 1999; van Wurff, 2004). In addition, this line of argument easily leads to the conclusion that public service remit should be limited to serving the underserved and underprivileged audience with commercially non-profitable content.

Of course, market analysts have vested interest in utilising analytic frames that lock people into the roles of consumers and segmented audiences, defined by specific consumer preferences (Nielsen, 2003: 243). The general premises of democratic media policy, however, are not conceived with respect simply to creating satisfied customers. At least this does not exhaust the meaning of the declarations on the value of freedom, pluralism and other routinely and consensually praised objectives of public media policies. Nielsen (2003: 243) states rather high-mindedly that: "By virtue of its empowering and enlightening objective, public cultural policy cannot be content with works or activities that only aim to please and confirm superficial preferences and opinions. On the contrary, an important element in the practice of public cultural policy is to create activities that challenge these immediate private preferences, and a central criterion for success and for quality, will be precisely whether these activities are capable of facilitating experimental processes that open the mind and senses of the public to something they didn't know they wanted". Although highbrow, the quote captures the contradiction between the logics of cultural policy and competition policy that seems so pervasive in contemporary media policy. Yet, it can't be assumed that this dilemma of pluralism will be solved by doing away with politics and turning political considerations into either private matters of individual choice or expert consideration.

\section{Conclusion}

The values and meanings associated with pluralism and diversity are open-ended and subject to continuous process of social negation, and it is not feasible to invoke an absolute final value or an authority (scientific, moral or political), to establish the relevant norms and criteria for their assessment. Nicholas Garnham (2000: 165-166) has noted that moral absolutes such as freedom of speech are especially susceptible to being mobilized for political interests because of their unquestioned and mythological status that prevents the critical examination of their premises. The core argument of this article is thus that questions of media structure and performance are essentially political and ideological questions that imply a dialogue between different values. Respectively, the choices made to assess the state of various demands posed to the structure of communication will depend, not only on the choice of objective method of assessment, but upon different visions of society and the public sphere. However, the recent trends of rationalisation or technocratisation of public policy point to growing incapacity to deal with such questions in political terms, as requiring not simply technical but properly politi- 
cal decisions. In response, there have been numerous calls in political theory to return to a more normative (and democratic) form of politics (Mouffe, 1993, 2000; Hay, 2004). In line with this aim, this paper set out to demystify and deconstruct some of the rationalist premises upon which public legitimation of media policy is premised on.

It can be claimed that this emphasis on public debate and democratic politics is rather uncontroversial, even revealing a fair amount of naïveté. There will always be need to make policy decisions on the distribution of various privileges and resources and base those decision on deficient information. Criticizing empirical assessment from the vantage point of political and normative ideals is perhaps too easy, since there are always trends that fall outside the chosen indicators and data, and these shortcomings in general need no reminder. Therefore, the biggest problem of such research is not that they are insufficient but that they create an illusion - although not entirely through their own fault - that questions of media diversity or media performance in general could ever be conceptually unambiguous problems that can be solved by technical means. From this perspective, diversity measurement should be seen more as an addition to media policy debate, rather than as an 'objective' technocratic instrument that provides the absolute criteria or authority to police the media.

A lot of the uneasiness raised by the questions of cultural evaluation and policy has to do with general problem of reflecting on values in both administrative and theoretical debates. As McQuail (1997) notes, the academic variant of media policy analysis has typically been long on 'realism', anxious to appear economically and technologically literate, and rather short on idealism and fundamental criticism. Cultural studies, on the other hand, shunning the formal legal-economic discourse, are more inclined to interpret or celebrate than to problematize or politicize. Although I have emphatically criticized the way diversity is conceptualized in the administrative policy research, it is not clear whether the reputedly more critical approaches of cultural analysis fare any better. In their incapacity or unwillingness to deal with the broader structures of communication and its political and social contexts, the mainstream of cultural studies has not contributed much to the debate on the norms and values of media regulation either (Ferguson \& Golding, 1997). Actually, many have argued that the stress on popular consumption, active audiences, and individual creation of meaning are actually rather complicit with the neo-liberal idea of consumer sovereignty (Gitlin, 1997; McGuigan, 1997; Garnham, 2000). Thus, repeated appeals to complexity, pluralism and contingency of media culture may also reflect the inability of researchers to really tackle the politically sensitive issues of media performance and the norms of evaluation.

As this growing uneasiness with the populism of much of the cultural studies indicates, it is becoming increasingly clear that the treacherous questions of value and quality can never be totally averted in cultural evaluation and policy-making. As McQuail (1997: 49) grudgingly concedes, "The only alternative to considered and coherent media policy seems to be the patently messy and intellectually incoherent attempt to uphold somewhat arbitrarily chosen values (with sometimes dubious undercurrents and allies)". Similarly, the criticism presented above is more suggestive and provocative than particularly analytic. It is not undesirable per se that broadcasters are accountable of their performance or that this is somehow monitored. But the developments I have discussed become problematic when the criteria developed for assessment begin to guide the overall norms and aims of public policy, and not the other way around. What can be expected from administrative, and especially scholarly, evaluation discourse is critical self-reflection in terms of the concepts, indicators and criteria they employ. In addition to devel- 
oping new criteria of assessment, there is a need to ask, what aspects do the existing criteria emphasise, what are their premises, and what political consequences they may have.

The present complexity and multiformity of media systems and media use itself precludes any attempts to impose any unambiguous criteria for assessing the public interest. In this situation of change in both media and policy, it can be argued the very nature of policy-making is changing, bringing about a need for new approaches to its analysis as well. With more positive aims, McQuail (1992: 312) as well as Van Cuilenburg (1998) have suggested that a revised agenda for performance assessment should put more attention to structures of provision and to audience and reception. In one recent attempt worth mentioning, a concept of 'social demand' has been proposed as a way of combining the policy studies and audience research (Raboy et al, 2003). As an empirical notion it distinguishes itself from the politico-philosophical notions of public interest, but it also goes beyond the individual preferences mediated by the market, the purpose being to seek new grounds to analyse the objectives off media policy, their legitimacy, and to produce useful and relevant information for the needs of public policy. Other comparable possibilities are many and beyond the scope of this paper, but in any case, it seems that relevant assessment of media performance - and engagement with diverse value choices inherent in the use of notions such as 'quality' or 'diversity' - for policy or other purposes requires a combination of various approaches. In terms of media diversity, the unsolved problem remains, how to conceptualize the need for pluralism and diversity, inherent in all normative accounts of the public sphere, without falling in the trap of relativism, indifference, and unquestioning acceptance of market-driven difference and consumerism.

In any case, what needs to be remembered with all assessment and evaluation is that means and ends ought to be kept separate. Setting political ends is a properly political and normative question that ought to guide the choice of means and methods, not the other way around. In the end, questions related to the normative ideals of media systems, quality, or public interest can never be measured by any other means than by public debate and deliberation. Attempts to cut corners and solve value questions once and for all, whether through invisible hand of the market or through scientific methods, are all equally weak.

\section{Notes}

1. In its broadest definition, media diversity refers to the heterogeneity on the level of contents, outlets, ownership or any other aspect of the media deemed relevant. Different frameworks have been suggested to analyze its different subcomponents, such as source, content, and exposure diversity, and their hierarchies and relations (see McQuail, 1992; Napoli, 1999; Hellman, 2001). There is also some confusion regarding the difference, or a possible hierarchy, between the concepts 'media diversity' and 'media pluralism'. Here, I will not make a systematic distinction but will primarily employ the concept 'media diversity', especially when referring to the empirical approaches, while pluralism is understood as a more diffuse social value. In any case, both function as umbrella terms or conceptual categories that I have no intention to define in the article.

2. The relationship between the number of media outlets and the diversity (however defined) of available content and the actual content that is watched is all but linear as a plethora of contradictory and ambiguous research on the effects of competition and ownership structures on content attest (see McQuail, 1992; Meier \& Trappel, 1998; van der Wurff, 2004; Aslama et al, 2004). 


\section{References}

Ang, Ien (1991) Desperately Seeking the Audience. London: Routledge.

Aslama, Minna, Heikki Hellman and Tuomo Sauri (2004) 'Does Market-Entry Regulation Matter?' Gazette: The International Journal for Communication Studies 66(2): 113-32.

Bauman, Zygmunt (1997) Postmodernity and its Discontents. Cambridge: Polity Press.

Bauman, Zygmunt (1999) In Search of Politics. Cambridge: Polity Press.

Collins, Richard (1998) From Satellite to Single Market: New Communication Technology and European Public Service Television. London: Routledge.

Coppens, Tomas (2004) 'Indicators of Freedom or Control? Assessing Performance Indicators for Belgian Public Broadcasters', Paper presented at the 2004 IAMCR Conference, Porto Alegre.

Curran, James (2002) Media and Power. London: Routledge.

Dean, Mitchell (1999) Governmentality. Power and Rule in Modern Society. London: Sage.

Doyle, Gillian (1997) 'From 'Pluralism' to 'Ownership': Europe's emergent policy on Media Concentrations navigates the doldrums', Journal of Information, Law and Technology 1997(3) <http:// elj.warwick.ac.uk/jilt/commsreg/97_3doyl/>

Feintuck, Mike (1999) Media Regulation, Public Interest and the Law. Edinburgh University Press.

Ferguson, Marjorie \& Golding, Peter (eds) (1997) Cultural Studies in Question. London: Sage.

Foucault, Michel (1991) 'Governmentality', in G. Burchell, C. Gordon and P. Miller (eds) The Foucault Effect. Studies in Governmentality. London: Harvester Wheatsheaf, pp. 87-104

Garnham, Nicholas (2000) Emancipation, the Media and Modernity. Oxford University Press.

Gibbons, Thomas (2000) 'Pluralism, Guidance and the New Media', in C. Marsden (ed) Regulating the Global Information Society. London: Routledge, pp. 304-15

Gitlin, Todd (1997) 'The Anti-political Populism of Cultural Studies', in M. Ferguson \& P. Golding (eds) Cultural Studies in Question. London: Sage, pp. 25-38

Habermas, Jürgen (1996) 'The Scientization of Politics and Public Opinion', in W. Outhwaite (ed) Habermas Reader. Cambridge. Polity Press, pp. 44-52 (originally in Habermas (1971) Towards a Rational Society)

Harrison, Jackie \& Woods, Lorna (2001) 'Defining European Public Service Broadcasting', European Journal of Communication 16(4): 477-504.

Hay, Colin (2002) Political Analysis: A Critical Introduction. Basingstoke: Palgrave.

Hay, Colin (2004) 'The Normalizing role of Rationalist Assumption in the Institutional Embedding of Neoliberalism', Economy and Society 33(4): 500-527.

Hellman, Heikki (1999) 'Legitimations of Television Programme Policies. Patterns of Argumentation and Dicursive Convergencies in a Multichannel Age', in P. Alasuutari (ed) Rethinking the Media Audience. London: Sage, pp. 105-29

Hellman, Heikki (2001) 'Diversity - An End in Itself? Developing a Multi-measure Methodology of Television Prigramme Variety Studies', European Journal of Communication 16(2): 181-208.

Howley, Kevin (2005) 'Diversity, Localism and the Public Interest: The Politics of Assessing Media Performance', International Journal of Media and Cultural Politics 1(1): 103-6.

Jakubowicz, Karol (2003) 'Bringing Public Broadcasting to Account', in G.F. Lowe and T. Hujanen (eds) Broadcasting \& Convergence. New Articulation of the Public Service Remit. Göteborg: Nordicom, pp. 147-66

Kaitatzi-Whitlock, Sophia (1996) 'Pluralism and Media Concentration in Europe. Media Policy as Industrial Policy', European Journal of Communication 11(4): 453-483.

Keane, John (1992) 'Democracy and the Media - Without Foundations', Political Studies XL (Special Issue): $116-127$.

Kymlicka, Will \& Norman, Wayne (eds) (2000) Citizenship in Diverse Societies. Oxford University Press.

McLennan, Gregor (1995) Pluralism. Buckingham: Open University Press.

McQuail, Denis (1992) Media Performance. Mass Communication and the Public Interest. London: Sage.

McQuail, Denis (1997) 'Policy Help Wanted. Willing and Able Media Culturalists Please Apply', in M. Ferguson \& P. Golding (eds) Cultural Studies in Question. London: Sage, pp. 39-55

McGuigan, Jim (1997) 'Cultural Populism Revisited', in M. Ferguson \& P. Golding (eds) Cultural Studies in Question. London: Sage, pp. 138-54

McGuigan, Jim (2004) Rethinking Cultural Policy. Maidenhead: Open University Press.

Meier, Werner E. and Joseph Trappel (1998) 'Media Concentration and the Public Interest', in D. McQuail and K. Siune (eds) Media Policy. Convergence, Concentration and Commerce. London: Sage, pp. 38-59.

Mouffe, Chantal (1993) The Return of the Political. London: Verso.

Mouffe, Chantal (2000) The Democratic Paradox. London: Verso. 
Nielsen, Henrik Kaare (2003) 'Cultural Policy and Evaluation of Quality', International Journal of Cultural Policy 9(3): 237-245.

Napoli, Philip M. (1999) 'Deconstructing the Diversity Principle', Journal of Communication 49(4): 7-34.

Pauwels, Caroline (1998): 'From Citizenship to Consumer Sovereignty: The Paradigm Shift in the European Audiovisual Policy', in A. Calabrese and J-C. Burgelman (eds) Communication, Citizenship, and Social Policy. Lanham: Rowman \& Littlefield, pp. 65-76

Raboy, Marc, Serge Proulx and Peter Dahlgren (2003) 'The Dilemma of Social Demand. Shaping Media Policy in New Civic Contexts', Gazette 65(4-5): 323-329.

Rose, Nikolas and Peter Miller (1992) 'Political Power Beyond the State: Problematics of Government', British Journal of Sociology 43(2): 173-205.

Rose, Nikolas (1999) Powers of Freedom. Reframing Political Thought. Cambridge University Press.

Sarikakis, Katherine (2004) Powers in Media Policy. The Challenge of the European Parliament. Oxford: Peter Lang.

Sunstein, Cass (2003) 'The Law of Group Polarization', in J. Fishkin and P. Laslett (eds) Debating Deliberative Democracy. Oxford: Blackwell, pp. 80-101.

Syvertsen, Trine (2003) 'Challenges to Public Television in the Era of Convergence and Commercialization', Television \& New Media 4(2): 155-175.

Van Cuilenburg, Jan (1998) 'Diversity Revisited: Towards a Critical Rational Model of Media Diversity', in K. Brants, J. Hermes and L. van Zoonen (eds) The Media in Question. London: Sage, pp. 38-49.

Van Cuilenburg, Jan and Denis McQuail (2003) 'Media Policy Paradigm Shifts. Towards a New Communications Policy Paradigm', European Journal of Communication 18(2): 181-207.

Van der Wurff, Richard (2004) 'Supplying and Viewing Diversity. The Role of Competition and Viewer Choice in Dutch Broadcasting', European Journal of Communication 19(2): 215-37.

Van Loon, Ad (2000) 'Freedom Versus Aceess Rights in a European Context', in C. Marsden (ed) Regulating the Global Information Society. London: Routledge, pp. 285-303.

Venturelli, Shalini (1998) Liberalizing the European Public Sphere. Politics, Regulation, and the Public Sphere. Oxford: Clarendon Press. 